\title{
The role of pelagic-benthic coupling in structuring littoral benthic communities at Terra Nova Bay (Ross Sea) and in the Straits of Magellan*
}

\author{
RICCARDO CATTANEO-VIETTI, MARIACHIARA CHIANTORE, CRISTINA MISIC, \\ PAOLO POVERO and MAURO FABIANO
}

Istituto di Scienze Ambientali Marine, Università di Genova, 16126 Genova - Italy. Fax: +39-10-3538069;

E-mail: catta@unige.it

\begin{abstract}
SUMMARY: In Antarctic and peri-Antarctic regions, benthic communities are persistent in time and show high biomass and large numbers of individuals, mainly consisting of suspension and deposit feeders. In fact, apart from recruitment, the major factor structuring these communities is the high flow of organic matter from the pelagic domain to the bottom, representing an important energy source for the benthic organisms. The aim of this paper is to review, compile and compare the data from earlier investigations in Terra Nova Bay (Ross Sea) and the Straits of Magellan, in order to come to a more general conclusion about the role of the pelagic-benthic coupling in structuring littoral benthic communities in southern coastal areas. Few measurements of flux rates and the biochemical composition of the sinking particles occurring in Antarctic and peri-Antarctic shallow waters are available, but a compilation of our own data and others allows a comparison of these two systems. The different environmental conditions between Antarctica and the Straits of Magellan lead to differences in the origin of the particulate organic matter and in its biochemical composition, and consequently in the coupling between pelagic and benthic domains. At Terra Nova Bay the summer particulate matter shows a high labile fraction of a good food value: its flux has been evaluated at about $0.67 \mathrm{~g} \mathrm{~m}^{-2} \mathrm{~d}^{-1}$. Conversely, the Straits of Magellan show multi-structured ecosystems where the quality and quantity of the organic matter flux towards the bottom change according to the local geomorphology and current dynamics. Moreover, the three-dimensional assemblages of suspension-feeders, so common in Antarctic shallow waters, seem to be absent in the Magellan area. In particular sponges, gorgonarians and bryozoans play a secondary role inside the Straits of Magellan, where polychaetes $(60 \%)$ and molluscs (9-10\%) are dominant on soft bottoms, and where they reach high values in density and biomass. Bivalves seem to play an important role in both regions: for instance, at Terra Nova Bay, the scallop Adamussium colbecki processes about $14 \%$ of the total carbon flux, with an assimilation efficiency of $36 \%$. This scallop seems to be able to adapt its reproductive period and its trophic behaviour to the changes in the quality and quantity of the pelagic events. The pulsing trend of the vertical flux, which in a few weeks can reach the total annual input, produces significant changes in the physiology (growth, reproduction, spawning) and trophic behaviour of many benthic species, such as sponges and polychaetes. The study of the pelagic-benthic coupling could be essential in the evaluation of the trophic capacity and the environmental response around sites of sea-farming, which are an ever-growing activity in the Magellan area.
\end{abstract}

Key words: Antarctica, Straits of Magellan, pelagic-benthic coupling.

RESUMEN: El PAPEL DEL ACOPLAMIENTO PELÁGICO-BENTÓNICO EN LA ESTRUCTURACIÓN DE LAS COMUNIDADES LITORALES Bentónicas en la Bahía de Terra Nova (Mar de Ross) y en el Estrecho de Magallanes. - En las regiones Antártica y periantártica, las comunidades bentónicas son persistentes en el tiempo y muestran altos valores de biomasa y número de individuos. Estas comunidades están constituídas, principalmente, por organismos suspensívoros y detritívoros. Aparte del reclutamiento, el factor más importante en estructurar estas comunidades es el flujo de materia orgánica desde la zona pelágica al bentos, lo que representa una importante fuente de energía para los organismos del fondo. No obstante la gran importancia de la producción primaria como suministro de alimento para las comunidades béntonicas litorales, la información sobre la tasa de flujo y la composición bioquímica del material que sedimenta es reducida. Muestreos rea-

*Accepted November 23, 1998. 


\begin{abstract}
lizados con trampas de sedimento han mostrado altos valores de flujo de materia orgánica caracterizado por una elevada presencia de paquetes fecales, particularmente importantes en el transporte de materia orgánica desde la zona fótica a las aguas profundas. En Bahía Terra Nova (Mar de Ross) la materia orgánica estival presenta una fracción lábil importante, un alto valor alimentario y un flujo que se evaluó en aproximadamente $0.67 \mathrm{~g} \mathrm{~m}^{-2} \mathrm{~d}^{-1}$. Las diferentes condiciones ambientales de la Antártida y el Estrecho de Magallanes ocasionan diferencias en el origen y en la composición bioquímica de la materia orgánica particulada y, consecuentemente, en el acoplamiento entre los dominios pelágico y bentónico. El Estrecho de Magallanes, contrariamente a las observaciones hechas en la Antártida, muestra un sistema de flujo de materia orgánica hacia el fondo , debido a su geomorfología peculiar y a la dinámica de las corrientes. Por otra parte, los agrupamientos tridimensionales de suspensívoros, comunes en las aguas someras antárticas, parecen estar ausentes en el área del Estrecho de Magallanes. Particularmente esponjas, gorgonias y briozoos desempeñan un papel secundario en el interior del Estrecho de Magallanes, donde poliquetos $(60 \%)$ y moluscos $(9-10 \%)$ dominan en los fondos blandos, alcanzando altos valores de densidad y biomasa. Los bivalvos desempeñan un papel importante en ambas regiones: en la Bahía de Terra Nova, el pectínido Adamussium colbecki procesa aproximadamente el 14\% del flujo total de carbono, con una eficiencia de asimilación del $36 \%$. Este pectínido sería capaz de adaptar su periodo reproductivo y su estrategia trófica a los cambios en la calidad y la cantidad de materia orgánica. Los pulsos del flujo vertical, que en pocas semanas puede alcanzar el suministro total anual, producen cambios significativos en la fisiología (crecimiento, reproducción, freza) y en el comportamiento trófico de algunas especies bentónicas, como esponjas y poliquetos. Finalmente, el estudio del acoplamiento bentos-pélagos puede ser esencial en la evaluación de la capacidad trófica y la respuesta ambiental para la ubicación de zonas de cultivos marinos, actividad en continuo crecimiento en el área de Magallanes.
\end{abstract}

Palabras clave: Antártica, Estrecho de Magallanes, acoplamiento pelágico-bentónico.

\section{INTRODUCTION}

In high productive marine areas, the major biological factor structuring benthic communities, excluding recruitment, is the flow of organic matter from the pelagic domain to the bottom. It may represent the main energy source for the heterotrophic benthic organisms (Graf, 1992). This is particularly true in Antarctica (Grebmeier and Barry, 1991), as well as in the Arctic, where the primary production, higher in coastal waters (83-170 $\mathrm{g} \mathrm{C} \mathrm{m}^{-2} \mathrm{y}^{-1}$ ) and over continental shelves than in oceanic waters (26 g C m${ }^{-2} \mathrm{y}^{-1}$; Wefer et al., 1988), occurs in a short summer time, with blooms of Phaeocystis (Palmisano et al., 1985; SooHoo et al., 1987) and/or diatoms (Krebs, 1983).

The influence of the organic matter in the water column on the benthos has been evidenced at McMurdo Sound: Dayton and Oliver (1977) observed strong quantitative and qualitative differences in the soft-bottom communities living in areas influenced by oligotrophic currents flowing from beneath the Ross Ice Shelf and those influenced by more eutrophic waters, flowing southward.

Several studies have been carried out on particle flux and sedimentation in Antarctica (Wefer et al., 1988; Peinert et al., 1989; Smetacek et al., 1990; Grebmeier and Barry, 1991; Knox, 1994). However, despite the great importance of the primary production as food supply in littoral and ice-covered waters, few measurements of the flux rate and the biochemical composition of the sinking particles are available from Antarctic and peri-Antarctic littoral areas.
In the shallow waters of Terra Nova Bay (Ross Sea), Fabiano et al. $(1996 ; 1997)$ found that the amount of total suspended matter (TSM) reaching the bottom during the summer (generally 30-40 days) can rise to $14 \mathrm{~g} \mathrm{~m}^{-2} \mathrm{~d}^{-1}$, practically $97 \%$ of the total flux as, during all other months, it is about 10100 times lower. This pulsing input supports numerous littoral benthic communities which are persistent in time, showing high biomass and large numbers of individuals. They are mainly constituted by deposit- and active and passive suspension feeders (sponges, bivalves, polychaetes, echinoderms), whose trophic strategies are strongly related to the flux occurring in the water column.

The aim of this paper is to compare the different environmental conditions occurring at a shallow water site in Antarctica (Terra Nova Bay, Ross Sea) and in the Straits of Magellan, paying particular attention to possible adaptations of suspension-feeders to face changes in the flux rates. Moreover, the Straits of Magellan, a peri-Antarctic area, show environmental conditions so different from those generally found along the Antarctic coasts, to be a significant place to study these phenomena under completely different hydrodynamic forces.

\section{PELAGIC-BENTHIC COUPLING IN TERRA NOVA BAY}

In Terra Nova Bay phytoplankton blooms occur during and immediately after the pack-ice melting (Fabiano et al., 1997). Significant differences can arise, linked to the annual sea-ice cover variation 
and upper layer stratification, e.g., if the pack-ice melting starts early in the season, and a second bloom occurs at the beginning of February. During the summer, inshore primary production at Terra Nova Bay can be evaluated as an average value of about 2-3 $\mathrm{mg} \mathrm{C} \mathrm{m}^{-3} \mathrm{~h}^{-1}$, but it is also important to take into account that, for a few days, the sympagic algae can reach the impressive primary production of about $500 \mathrm{mg} \mathrm{C} \mathrm{m}^{-3} \mathrm{~h}^{-1}$ with biomass values ranging about $1-7 \mathrm{~g} \mathrm{Chl-} a \mathrm{~m}^{-3}$ and making a heavy contribution to the final flux (Lazzara et al., 1995).

Another organic source comes from the benthic algae. Between 3 and $10 \mathrm{~m}$ depth, Iridaea cordata reaches a density of 4,336 plants $\mathrm{m}^{-2}$ in January, but the highest biomass value (about $3.5 \mathrm{~kg} \mathrm{~m}^{-2} \mathrm{WW}$ ), at the beginning of summer, suggests that it also grows, although at a low rate, during the Antarctic winter. Deeper, from 10 to $25 \mathrm{~m}$, Phyllophora antarctica forms dense and expansive beds, reaching its highest density and biomass values (about 10,000 plants $\mathrm{m}^{-2}, 1.5 \mathrm{~kg} \mathrm{~m}^{-2} \mathrm{WW}$, respectively) at the end of January (Cormaci et al., 1996).

Moreover, all the bottoms, down to $150-200 \mathrm{~m}$ depth, show a patchy distribution of highly dense seasonal populations of benthic diatoms, revealed by greenish layers seen using a ROV. Their biomass ranges from 4 to $80 \mu \mathrm{g} \mathrm{Chl-} a \mathrm{~g} \mathrm{~g}^{-1}$, with an average value of around $10 \mu \mathrm{g}$ Chl- $a \mathrm{~g}^{-1}$ (A. Pusceddu, pers. comm.).
In January the intense flux of living diatoms, organic matter and fecal pellets can reach $0.69 \mathrm{~g}$ POC $\mathrm{m}^{-2} \mathrm{~d}^{-1}$. The high values of TSM/POC sometimes recorded in the same period (Fabiano et al., 1997) depend on the large amount of inorganic matter due to eolic input, which varies greatly (3-300 g $\left.\mathrm{m}^{-2} \mathrm{y}^{-1}\right)$ according to the distance from the rocky outcrop.

The organic flux (Fig. 1) from the water column supports large littoral zoobenthic communities dominated by suspension- and deposit feeders (scallops, sponges and polychaetes). At Terra Nova Bay, the soft bottoms, between 20-30 and 60-70 m depth, are completely covered by the large scallop Adamussium colbecki, which reaches high biomass (100-120 $\mathrm{g} \mathrm{m}^{-2}$ DW soft tissues) and density (60-80 ind. $\mathrm{m}^{-2}$ ) values (Cattaneo-Vietti et al., 1997). Between 80 and $120 \mathrm{~m}$ depth, hard bottoms are dominated by filter-feeding assemblages, mainly characterized by sponges which can reach very high biomass values (over 2-3 $\mathrm{kg} \mathrm{m}^{-2} \mathrm{WW}$; Cattaneo-Vietti, unpublished data). Polychaetes (mainly Spiophanes tcherniai) are dominant below $100 \mathrm{~m}$ depth, reaching abundance values of 3,000 ind. $\mathrm{m}^{-2}$, exceeding $20 \mathrm{~g} \mathrm{~m}^{-2}$ WW of biomass (Gambi et al., 1997).

All these species play a key role in transferring energy from the water column to the benthos, a behaviour that allows them to reach high biomass values. For example, considering the average filter-

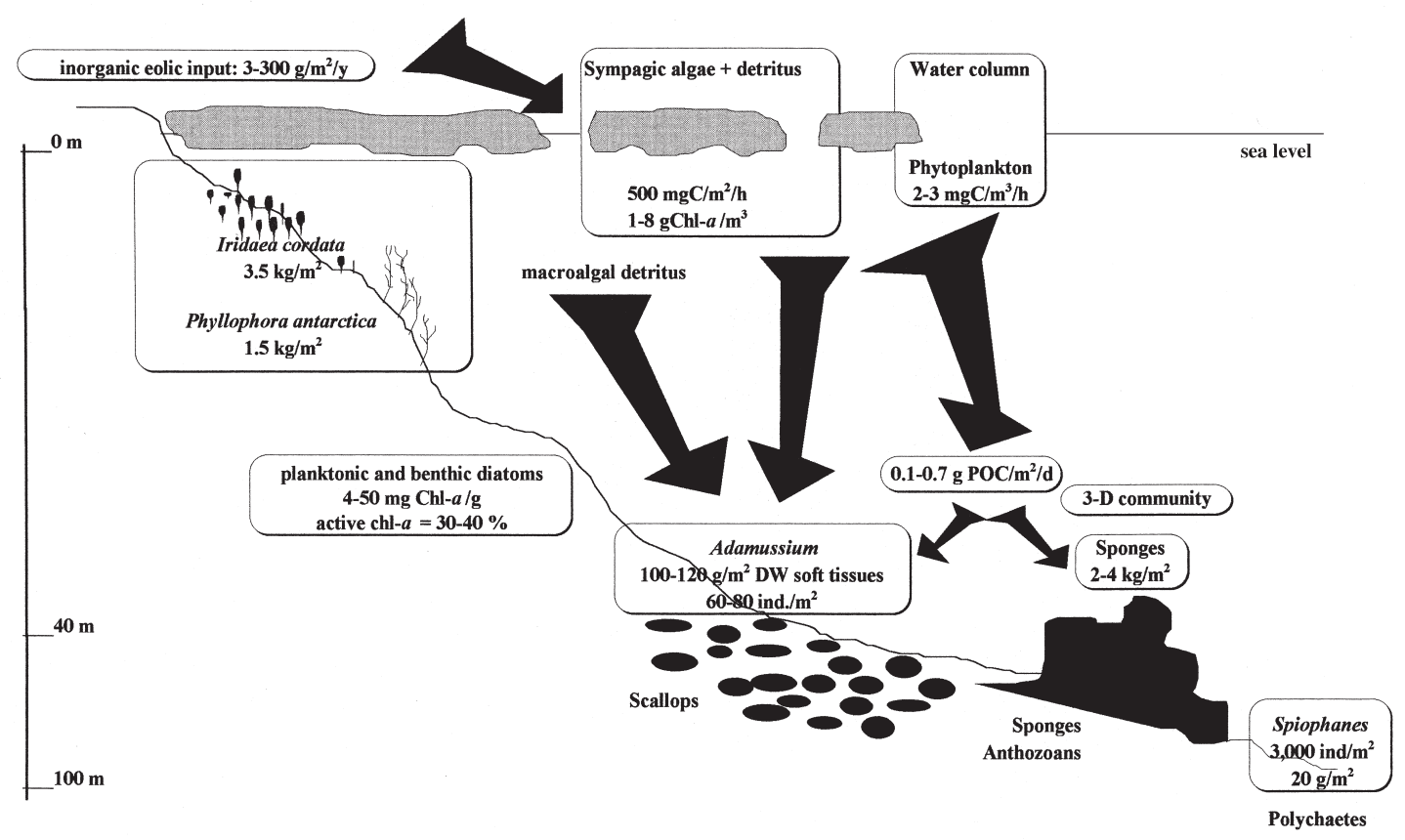

FIG. 1. - Scheme showing the main pathways of the organic flux at a littoral site in Terra Nova Bay (Ross Sea). 


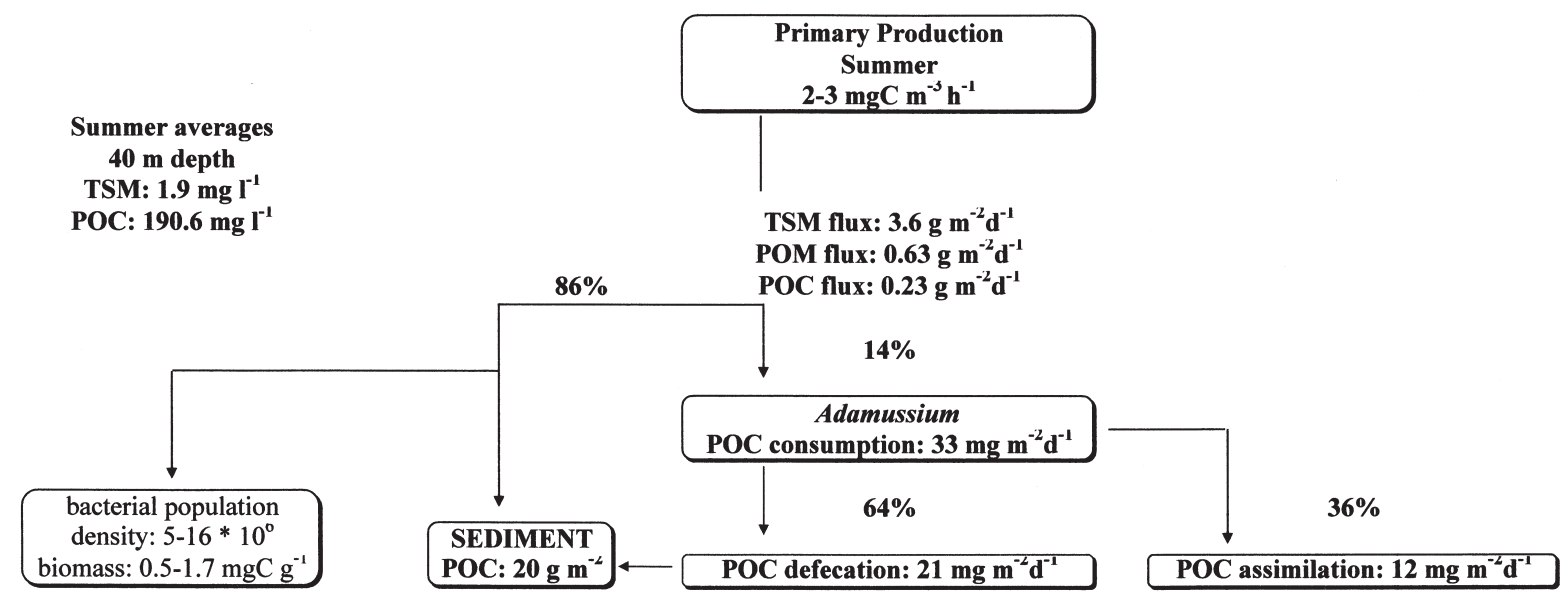

FIG. 2. - Scheme showing the pelagic-benthic coupling, measured as flux of POC, through the littoral scallop Adamussium colbecki at $40 \mathrm{~m}$ depth (Terra Nova Bay, Ross Sea). Summer primary production, measured total suspended matter (TSM), organic matter (POM) and organic carbon (POC) fluxes, TSM and POC concentration at $40 \mathrm{~m}$ depth and utilisation by Adamussium colbecki are reported. The POC assimilation of this scallop reaches about $4-5 \%$ of the summer primary production (from Chiantore et al., 1998, modified).

ing rate of Adamussium colbecki, of about $1 \mathrm{l} \mathrm{h}^{-1} \mathrm{~g}{ }^{-1}$ DW soft tissues, and the biodeposition rate, measured as faecal pellet production, of about 5-6 mg DW g ${ }^{-1}$ DW soft tissues $\mathrm{d}^{-1}$ (Chiantore et al., 1998), it is possible to estimate that the $\mathrm{C}_{\text {org }}$ flux, through $A$. colbecki towards the bottom, is about $21 \mathrm{mg} \mathrm{C} \mathrm{m}^{-2} \mathrm{~d}^{-1}$. Locally this scallop may process about $14 \%$ of total carbon flux from the water column to the sediments, with an assimilation efficiency of $36 \%$ (Fig. 2). A large part of the flux is also utilized by bacterial communities, with densities $\left(\mathrm{n} \mathrm{g}^{-1}\right)$ varying between $8.7 * 10^{5}$ and $1.56 * 10^{8}$ with an average biomass of $8.3 \mu \mathrm{g} \mathrm{C} \mathrm{g}^{-1}$ (A. Pusceddu, unpublished data; Fabiano et al., 1995).

The summer food supply increase may influence the life cycle of many benthic species: the comparison between the gonado-somatic indices in Adamussium colbecki populations in December and in January shows, in fact, that sexual maturity is reached late in summer, closely linked to the phytoplankton bloom (Chiantore et al., 1998).

The flux of organic matter, being quantitatively variable during the year, could represent a metabolic constraint for suspension feeders when the winter oligotrophic condition occurs (Matsuda et al., 1987). But suspension-feeding communities are persistent in time and they do not seem to show significant differences between summer and winter, when the maximum oligotrophy is reached. All this could be faced and overcome thanks to different adaptations with a change of the trophic behaviour during the year (Barnes and Clarke, 1994).

Suspension-feeding polychaetes could easily become deposit feeders, while the large bivalve
Adamussium, using clapping activities, seems to be able to resuspend the sunken organic matter (Chiantore et al., 1998). In this species, it is also possible to note a change in its behaviour: the juveniles are bissally attached on the free adults and use the organic matter resuspended by the clapping of the adults (Ansell et al., 1998). Other forms of epibiosis, adopted by serpuloids, bryozoans, holothurians and ophiuroids, are frequent in well structured communities and could be considered an adaptation to find better feeding conditions above the seafloor (Arntz et al., 1994).

Another example of change in the trophic strategy to overcome the oligotrophic period and to face the severe fluctuations in food availability in the environment has been described in sponges. Many demosponges take up and store planktonic and benthic diatoms by phagocytic activity (Gaino et al., 1994). This new functional adaptation is confirmed by the high Chl- $a$ and Chl- $c$ values extracted from several sponges collected from Terra Nova Bay at 80-120 m depth (Cattaneo-Vietti et al., 2000).

Particularly rich and 3-dimensionally structured communities (Fig. 3) develop in areas characterized by the presence of sponge spicule mats (Dearborn, 1967; Koltun, 1968; Dayton et al., 1974; Barthel, 1992): the amount of Chl- $a$, biomass and species richness increase in comparison with spicule-free sediments. A possible explanation is the fact that sponge spicules, creating a 3-D substratum, favour diatom population development, probably supported by the capacity of the opale spicules to channel light as natural optical fibres (Cattaneo-Vietti et al., 1996). 

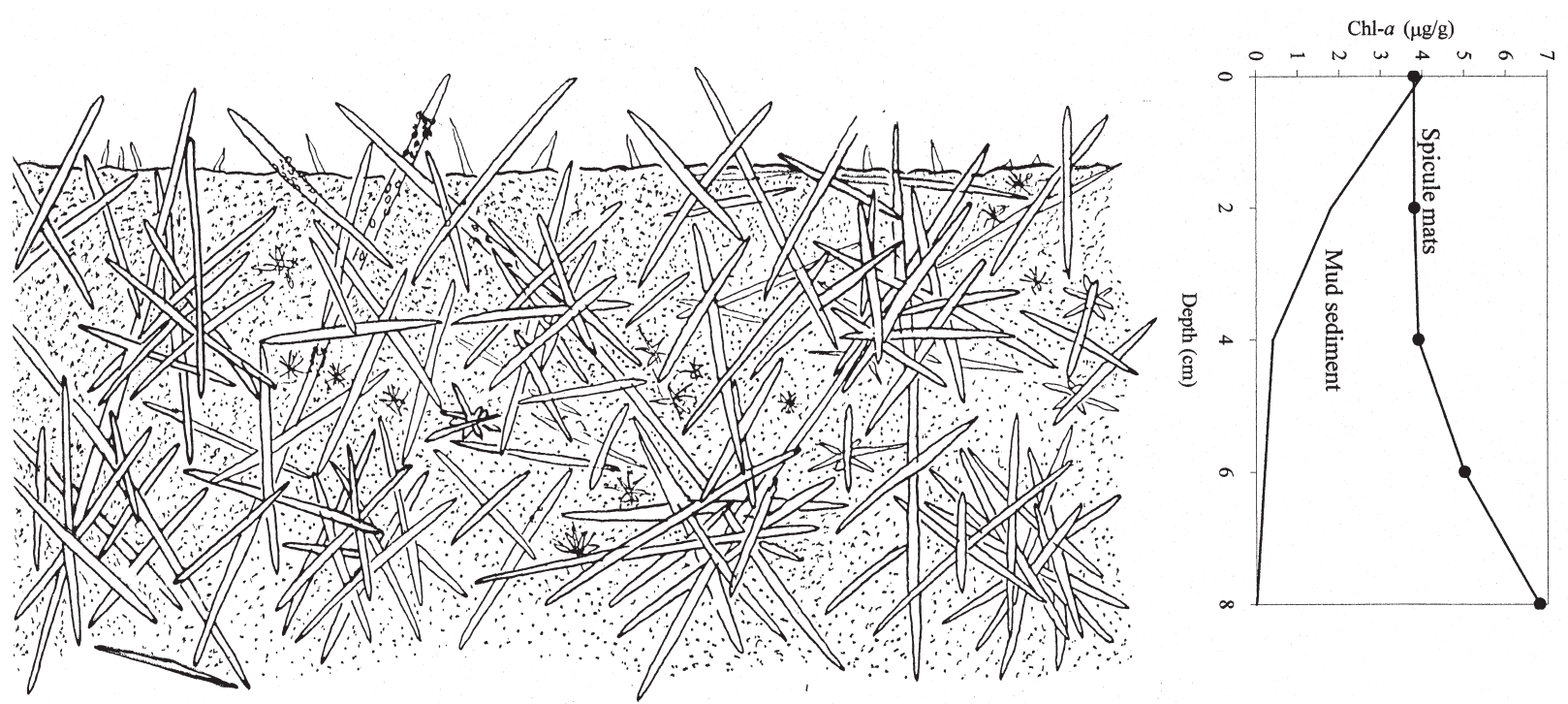

FIG. 3. - Scheme of the superficial texture of a spicule mat in a soft-bottom at Terra Nova Bay (Ross Sea), showing sponge spicules in the sediments. The amount of Chl- $a$ inside the sediments rich in spicules does not change in the first $5 \mathrm{~cm}$ depth.

\section{PELAGIC-BENTHIC COUPLING IN THE STRAITS OF MAGELLAN}

In contrast to the rather uniform environment at Terra Nova Bay, the Straits of Magellan, a $570 \mathrm{~km}$ long V-shaped channel between Southern Patagonia and Tierra del Fuego, show a complex geomorphology, turbulent tidal currents, different precipitation rates and fresh water inputs. No studies on the pelagic-benthic coupling in this area have been made, but available data regarding some water column parameters (TSM, Chl- $a$, POC, C:N) suggest that it may be considered as a multi-structured system with strong spatial differences in the composition and origin of the particulate organic matter. Thanks to the rich variety of sills and shelves, it is possible to distinguish at least three well defined sectors (Fig. 4): the Angosturas connect the Straits with the Atlantic and are characterized by a series of narrows and bays in which tidal amplitudes vary from 8 to $1.5 \mathrm{~m}$ and the shallow bottoms $(30-50 \mathrm{~m})$ are mainly constituted by gravel; Paso Ancho represents the wider part of the channel, characterized by mud and sandy mud bottoms and a maximum depth of $400 \mathrm{~m}$; and the Pacific section, from Cabo Froward to the Pacific, shows depths down to 1100 $\mathrm{m}$ and is characterized by important glacio-fluvial runoff constituting coarse sediments.

These sectors have different hydrological and trophic characteristics. The Angosturas are dominated by resuspension processes due to the strong currents $\left(4.5 \mathrm{~m} \mathrm{sec}^{-1}\right)$, consequently TSM is high (> $\left.2 \mathrm{mg}^{-1}\right)$, TSM/POC high (16.36) and the quality of the organic matter is generally poor, as suggested by the high ratio between $\mathrm{C}$ and $\mathrm{N}(\mathrm{C}: \mathrm{N}>7$; Carrada $e t$ al., 1994).

Paso Ancho shows a well stratified system, characterized by feeble currents near the bottom (up to $35 \mathrm{~cm} \mathrm{sec}^{-1}$; Budillon et al., 1997), autotrophic conditions (1-2 Chl- $a \mu \mathrm{g} \mathrm{l}^{-1}$ up to $7 \mathrm{Chl}-a \mu \mathrm{g} \mathrm{l}^{-1}$ in November; Panella et al., 1991; Antezana et al., 1996), evidencing a high primary production (0.5-1 mg C m ${ }^{-3} \mathrm{~h}^{-1}$; Saggiomo et al., 1994; Saggiomo and Mangoni, 1997). Nanoplankton density reaches $10^{5}$ $10^{7}$ cells $1^{-1}$ (Vannucci and Bruni, 1997), while phytoplankton density is about 10,000 cells $1^{-1}$ (Iriarte et al., 1997). The biochemical composition of the suspended particulate matter is rich in proteins $(\mathrm{C}: \mathrm{N}<$ 6), suggesting a high food value.

In the third area, towards the Pacific Ocean, the particulate matter is characterized by large amounts of heterotrophic detritus $\left(0.36 \mathrm{Chl}-a \mu \mathrm{g} \mathrm{l}^{-1}\right)$ of quite low energetic value $(\mathrm{C}: \mathrm{N}=6.07$; Carrada et al., 1994).

Considering the different hydrodynamic conditions, the quantity and the biochemical composition of the organic particulate matter of the considered sectors, it is reasonable to suppose that important biological coupling processes may occur mainly in Paso Ancho.

In the Magellan Region, many data are available regarding the structure and distribution of species of economic interest, such as the kelp Macrocystis pyrifera (Vasquez et al., 1984; Santelices, 1989), the mussels or choritos Aulacomya ater, Choromytilus chorus, Mytilus chilensis (Miranda and Acuña, 1979; 
Mesotidal regime

1-2 m

Pacific Channel strong currents depth : $1,000 \mathrm{~m}$ fresh water input
Paso Ancho current speed: $30 \mathrm{~cm} / \mathrm{sec}$ depth: $200 \mathrm{~m}$
Macrotidal regime

$7 \mathrm{~m}$

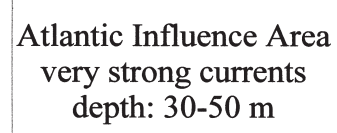

depth: 30-50 m

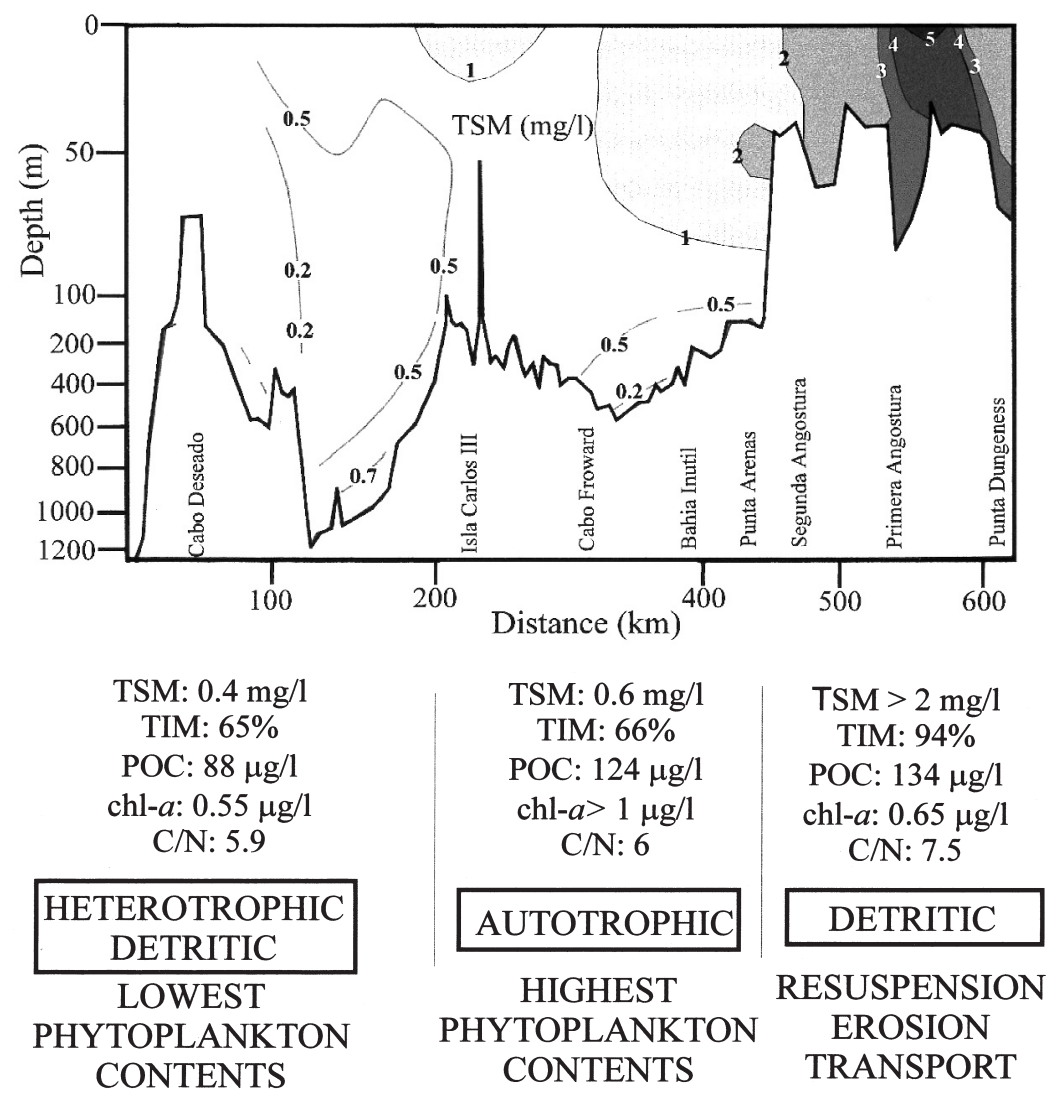

FIG. 4. - Scheme showing the different sectors into which the Straits of Magellan can be classified according to different trophic parameters (TSM = Total Suspended Matter; TIM = Total Inorganic Matter; POC $=$ Particulate Organic Carbon; chl- $a=$ chlorophyll $-a ; \mathrm{C} / \mathrm{N}=$ Particulate Organic Carbon/Particulate Organic Nitrogen ratio). The isolines indicate water masses of different contents of TSM (from Fontolan and Panella, 1991, modified).

Langley et al., 1980) the scallop or ostión Chlamys (Zygochlamys) patagonica, the loco Concholepas concholepas (Guzmán et al., 1987a;b), the crabs or centolla Lithodes santolla (Campodónico and Oyarzún, 1991; Vinuesa, 1991; Oyarzún, 1992) and centollón Paralomis granulosa (Campodónico, 1977), the langostino Munida subrugosa (Rodríguez and Bahamonde, 1986), and the erizo Loxechinus albus, but little information is available as regards the structure and composition of the benthic communities. This does not show evidence of possible relationships between the different trophic conditions and community distributions, but some considerations can be made. In the Angosturas (Langley et al., 1980) and in Paso Ancho (Miranda and Acuña,
1979), the intertidal and subtidal rocky zones are dominated by mussels which can reach high covering values (90\%) and densities (up to 120-150 ind. $\mathrm{m}^{-2}$ ), together with the limpet Nacella magellanica (up to 8 ind. $\mathrm{m}^{-2}$; Guzmán, 1978; Guzmán and Ríos, 1987). Kelp (Macrocystis pyrifera) forests (Ojeda and Santelices, 1984; Santelices, 1989) are present in the sheltered areas of the channel, reaching high biomass values. Their densities are controlled by sea star and sea urchin activities (Castilla, 1985). The intertidal soft-bottom communities are very poor, dominated by filamentous green algae (Enteromorpha spp., Ulothrix flacca) and large populations of the deposit-feeding amphipod Paramoera fissicauda (Langley and Lembeye, 1977). 
The sublittoral benthos reaches high values, in terms of abundance and biomass, in shallow water $(15-130 \mathrm{~m})$ and is characterized by bivalves (Chlamys patagonica), decapods (Munida subrugosa), asteroids and echinoids, with large populations of deposit feeders and scavenging crustaceans (Arntz et al., 1996; Gorny et al., 1996) and, where strong floor currents are missing, brachiopods (Gutt and Schickan, 1996). The infauna is dominated by polychaetes $(60 \%)$ and molluscs $(9-10 \%)$, reaching high values in density and biomass (Gerdes, 1996). The hard bottoms, so common in Antarctic shallow waters, are rare here and no 3-D communities of suspension feeders, comparable to those present in Antarctica, have been found. In particular, sponges, gorgonarians, bryozoans and crinoids seem to play a secondary role.

\section{CONCLUSIONS}

In the shallow waters of Terra Nova Bay, the lack of physical disturbance (excluding occasional events such as anchor ice and scouring) favours the development of well-structured benthic communities which depend mainly on the pulse-like particulate organic matter flux. If the environmental conditions are favourable, it supports a strong development of suspension-feeding communities, dominated at different depths by sponges, bivalves, brachiopods, polychaetes and echinoderms. This vertical flux (Fig. 1), which in a few weeks can reach the total annual input, produces significant changes in the physiology (growth, reproduction, spawning) and in the trophic behaviour of many benthic species. Finally, seasonally restricted availability of food may force organisms to save energy by adopting low metabolic rates and slow growth, while many suspension-feeding species seem to be able to take advantage of smaller size particles or to shift to deposit-feeding behaviour with surprising facility.

Conversely, the Straits of Magellan (Fig. 4) are generally dominated by strong currents and the organic input controlled by turbulent diffusion which brings large amounts of detritus. Intense processes of inorganic matter resuspension, occurring mainly in the Angosturas and in the Pacific Channel, reduce the trophic value of the flux, and consequently the benthic communities are poor and less structured. The sessile taxa that are so dominant in Antarctic waters, such as sponges, gorgonarians, and bryozoans, are not so common inside the Straits of Magellan probably because the elevated inorganic component (TIM) can impede and even damage their filtering structures. Accordingly, the communities are dominated by deposit feeders, scavengers and omnivores, such as crustacean decapods. Anyway, bivalves, reaching high values of biomass and density, play an important role in the coupling processes in both areas.

Food input from the water column may sometimes be insufficient to cover the requirements of some communities which reach high values of biomass and density (Arntz et al., 1994) suggesting a lateral advection of suspended matter as an additional resource. At Terra Nova Bay and at Paso Ancho, large macroalgal communities can certainly support this secondary input, which is used by large deposit-feeding populations of crustaceans.

Finally, it is import to underline that studies on the pelagic-benthic coupling also have an applied significance and could be essential in the evaluation of the trophic capacity and the environmental response in the location of sea-farming sites, which is an ever-growing activity in the Magellan region. These activities will in fact play an important role in changing the pristine features of the Magellan environment, determining more or less heavy phenomena of dystrophy, through the input of high amounts of catabolites and particulate organic matter.

\section{ACKNOWLEDGEMENTS}

The authors thank the AWI (Alfred Wegener Institute, Bremerhaven) and the University of Magallanes for inviting one of them (RCV) to participate in the IBMANT ' 97 workshop held at Punta Arenas (Chile). Our work was partially supported by the Italian Programme for Antarctic Studies (PNRA).

\section{REFERENCES}

Ansell, A.D., R. Cattaneo-Vietti and M. Chiantore. - 1998. Swimming in the Antarctic scallop Adamussium colbecki: analysis of in situ video recordings. Antarct. Sci., 10: 369-375.

Antezana, T., M. Hamame, Y. Eissler and S. Jara. - 1996. Traits of phytoplankton and zooplankton from the Straits of Magellan to Beagle Channel on board R/V Victor Hensen leg 1 and 2, OctNov 1994. Ber. Polarforsch., 190: 23-31.

Arntz, W.E., T. Brey and V.A. Gallardo. - 1994. Antarctic zoobenthos. Oceanogr. Mar. Biol. Ann. Rev., 32: 241-304.

Arntz, W.E., M. Gorny, M. Lardies, M. Mutschke and C. Ríos. 1996. Benthic macrofauna sampled with the Agassiz trawl. Ber. Polarforsch., 190: 43-50.

Barnes, D.K.A. and A. Clarke. - 1994. Seasonal variation in the feeding activity of four species of Antarctic Bryozoa in relation to environmental factors. J. Exp. Mar. Biol. Ecol., 181: 117-133. 
Barthel, D. - 1992. Do hexactinellids structure Antarctic sponge associations? Ophelia, 36: 111-118.

Budillon, G., J. Henríquez, M. Sobarzo and G.C. Spezie. - 1997. Hydrodynamics of the Straits of Magellan (1995). In: F.M. Faranda and L. Guglielmo (eds), Straits of Magellan, Oceanographic Cruise 1995. Data Report. pp. 9-52.

Campodónico, G.I. - 1977. Algunos aspectos biológico-pesqueros del recurso centollón Paralomis granulosa (Jacquinot) (Decapoda, Anomura, Lithodidae) en el Estrecho de Magallanes. Ans. Inst. Patagonia, 8: 363-373.

Campodónico, G.I. and S. Oyarzún. - 1991. Cultivo de centolla (Lithodes antarcticus) con fines de repoblación. Ia. Parte: Metamorfosis de postlarva a primer juvenil y crianza de larvas y postlarvas a escala intermedia. Informe Final, FONDECYT, pp 1-29.

Carrada, G.C., M. Fabiano, P. Povero and V. Saggiomo. - 1994. Surface distribution of size-fractionated chlorophyll-a and particulate organic matter in the Strait of Magellan. Polar Biol., 14: $447-454$

Castilla, J.C. - 1985. Food web and functional aspects of the kelp Macrocystis pyrifera community in the Beagle Channel, Chile. 4. SCAR Symposium of Antarctic Biology Wilderness (South Africa), 12-16 Sept. 1985. In: W.R Siegfried, P.R. Condy and R.M. Laws (eds), Antarctic Nutrient Cycles and Food Webs, pp. 407-414. Springer Verlag, Berlin, Heidelberg, New York.

Cattaneo-Vietti, R., G. Bavestrello, C. Cerrano, M. Sarà, U. Benatti, M. Giovine and E. Gaino. - 1996. Optical fibres in an Antarctic sponge. Nature, 383: 397-398

Cattaneo-Vietti, R., M. Chiantore and G. Albertelli. - 1997. The population structure and ecology of the Antarctic scallop, Adamussium colbecki at Terra Nova Bay (Ross Sea, Antarctica). In: J.-D. Ros and A. Guerra (eds), Ecology of Marine Molluscs. Sci. Mar., 61(Sup. 2): 15-24.

Cattaneo-Vietti, R., G. Bavestrello, C. Cerrano, E. Gaino, L. Mazzella, M. Pansini and M. Sarà. - 2000. The role of sponges in the Terra Nova Bay ecosystem. In: F.M. Faranda, L. Guglielmo and A. Ianora (eds), Ross Sea Ecology: Italian Antarctic Expeditions (1986-1995), pp. 539-549. Springer-Verlag, Berlin.

Chiantore, M., R. Cattaneo-Vietti, G. Albertelli, C. Misic and M. Fabiano. - 1998. Role of filtering and biodeposition by Adamussium colbecki in circulation of organic matter at Terra Nova Bay (Ross Sea, Antarctica). J. Mar. Syst., 17: 411-424.

Cormaci, M, G. Furnari, B. Scammacca and G. Alongi. - 1996. Summer biomass of a population of Iridaea cordata (Gigartinaceae, Rhodophyta) from Antarctica. In: S. C. Lindstrom and D. J. Chapman (eds), Proceedings of the XV Seaweed Symposium. Hydrobiologia, 326-327: 267-272.

Dayton, P.K. and J.S. Oliver. - 1977. Antarctic soft-bottom benthos in oligotrophic and eutrophic environments. Science, 197: 55-58.

Dayton, P.K., G.A. Robilliard, R.T. Paine and L.B. Dayton. - 1974. Biological accomodation in the benthic community of McMurdo Sound, Antarctica. Ecol. Monogr., 44: 105-128.

Dearborn, J.H. - 1967. Stanford University invertebrates studies in the Ross Sea (1958-61): general account and station list. In: The Fauna of the Ross Sea. Part 5. NZ Dep. Sci. Industr. Res. Bull., 176: 31-48.

Fabiano, M., R. Danovaro, E. Crisafi, R. La Ferla, P. Povero and L. Acosta Pomar. - 1995. Interrelationship between particulate organic matter and bacteria in Terra Nova Bay. Polar Biol., 15: 393-400.

Fabiano, M., M. Chiantore, P. Povero, R. Cattaneo-Vietti, A. Pusceddu, C. Misic and G. Albertelli. - 1997. Short-term variations in particulate matter flux in Terra Nova Bay, Ross Sea, Antarctica. Antarct. Sci. 9 (2): 143-149.

Fabiano, M., P. Povero and R. Danovaro. - 1996. Particulate organic matter composition in Terra Nova Bay (Ross Sea, Antarctica) during summer 1990. Antarct. Sci., 8 (1): 7-13.

Fontolan, G. and S. Panella. - 1991. Distribution and chemistry (Fe, $\mathrm{Zn}, \mathrm{Pb}, \mathrm{Cu}, \mathrm{Cd}$ and Chlorophyll- $a$ ) of suspended particulate matter in the Strait of Magellan: Austral spring 1989. Boll. Ocean. Teor. Appl., 9: 179-191.

Gaimo, E., G. Bavestrello, R. Cattaneo-Vietti and M. Sara. - 1994. Scanning electron microscope evidence for diatom uptake by tow Antarctic sponges. Polar Biol., 14: 55-58.

Gambi, M.C., A. Castelli and M. Guizzardi. - 1997. Polychaete populations of the shallow soft bottoms off Terra Nova Bay (Ross Sea, Antarctica): distribution, diversity and biomass. Polar Biol., 17: 199-210.
Gerdes, D. - 1996. Preliminary results of the multibox corer investigations. Ber. Polarforsch., 190: 41-42.

Gorny, M., W. Arntz and R. Soto. - 1996. Report on the anomuran and brachyuran crabs. Ber. Polarforsch., 190: 60-63.

Graf, G. - 1992. Benthic-pelagic coupling: a benthic view. Oceanogr. Mar. Biol. Ann. Rev., 30: 149-190.

Grebmeier, J.M. and J.P. Barry. - 1991. The influence of oceanographic processes on pelagic-benthic coupling in polar regions: a benthic perspective. J. Mar. Syst., 2: 498-518.

Gutt, J. and T. Schickan. - 1996. Epibenthic communities analyzed by underwater camera. Ber. Polarforsch., 190: 35-41.

Guzmán, L.M. - 1978. Patrón de distribución espacial y densidad de Nacella magellanica (Gmelin, 1791) en el intermareal del sector oriental del Estrecho de Magallanes (Mollusca, Gastropoda). Ans. Inst. Patagonia, 9: 205-219.

Guzmán, L.M. and C. Ríos. - 1987. Age and growth of the subantarctic limpet Nacella (Patinigera) magellanica magellanica (Gmelin, 1791) from the Strait of Magellan, Chile. Veliger, 30(2): 159-166.

Guzmán, L., C. Ríos, M. Ibarra and S. Oyarzún. - 1987a. Investigación Banco de Ostiones y Locos. I. Recurso "loco" Concholepas concholepas (Bruguiere, 1789). Informe Final, Inf. Inst. Patagonia, 37: 1-94.

Guzmán, L., C. Ríos, M. Ibarra and S. Oyarzún. - 1987b. Investigación Banco de Ostiones y Locos. II. Recurso "ostión" Chlamys (Zygochlamys) patagonica (King and Broderips). Informe Final, Inf. Inst. Patagonia, 38: 1-86.

Iriarte, J.L., S. Basualto, D. Marino and J.C. Uribe. - 1977. Distribution of phytoplankton in the Straits of Magellan (MarchApril 1995). In: F.M. Faranda and L. Guglielmo (eds): Straits of Magellan, Oceanographic Cruise 1995. Data Report. 141170 .

Knox, G.A. - 1994. The Biology of the Southern Ocean. Cambridge University Press.

Koltun, V.M. - 1968. Spicules of sponges as an element of the bottom sediments of the Antarctic. In: SCAR Symposium on Antarctic Ocean, pp.121-123. Scott Polar Research Institute, Cambridge.

Krebs, W.N. - 1983. Ecology of neritic marine diatoms, Arthur Harbour, Antarctica. Micropaleontol., 29: 267-297.

Langley, S. and G. Lembeye. - 1977. Algunos antecedentes sobre el macrobentos, granulometría y contenido de petroleo en los sedimentos de dos estradas de mar en Puerto Espora (Tierra del Fuego) contamidados por el derrame del B/T Metula. Ans. Inst. Patagonia, 8: 375-388.

Langley, S., L.M. Guzmán and C. Ríos. - 1980. Aspectos dinámicos de Mytilus chilensis (Hupoe, 1840) en el Estrecho de Magallanes. I. Distribución, densidad y disposición espacial en el intermareal. Ans. Inst. Patagonia, 11: 319-332.

Lazzara, L., C. Nuccio, L. Massi and M. Innamorati. - 1995. Le microalghe simpagiche di Baia Terra Nova (Antartide), nell'estate 1994/95. Giornale Bot. Italiano, 129: 425.

Matsuda, O., S. Ishikawa and K. Kawakuchi. - 1987. Seasonal variations of downward flux of particulate organic matter under Antarctic fast ice. Proc. NIPR Symp Polar Biol, 1: 23-34

Miranda, O. and E. Acuña. - 1979. Mytilus edulis chilensis (Hupe, 1854) en Cabo Negro (Provincia de Magallanes). Rev. Biol. Mar. Dep. Oceanol. Univ. Chile, 16: 331-353.

Ojeda, F.P. and B. Santelices. - 1984. Invertebrate communities in holdfasts of the kelp Macrocystis pyrifera from Southern Chile. Mar. Ecol. Prog. Ser., 16: 65-73.

Oyarzún, S. - 1992. Cultivo de centolla (Lithodes antarcticus) con fines de repoblación. Ia. Parte: Metamorfosis de postlarva a primer juvenil y crianza de larvas y postlarvas a escala intermedia. Informe Final. Fundación Andes: 1-37.

Palmisano, A.C., J.B. SooHoo, D.C. White, G.A. Smith, G.R. Stanton and R.H. Burckle. - 1985. Shade adapted benthic diatoms beneath Antarctic sea ice. J. Phycol., 21: 664-667.

Panella, S., A. Michelato, R. Perdicaro, G. Magazzù, F. Decembrini and P. Scarazzato. - 1991. A preliminary contribution to understanding the hydrological characteristics of the Strait of Magellan: Austral spring 1989. Boll. Ocean. Teor. Appl., 9: 107-126.

Peinert, R., B. von Bodungen and V. Smetacek. - 1989. Food web structure and loss rates. In: W. Berger, V. Smetacek and G. Wefer (eds), Productivity in the Ocean: Present and Past, pp. 34-48. Wiley, New York.

Rodríguez, O.L. and F.R. Bahamonde. - 1986. Estimación del crec- 
imiento y mortalidad natural en Munida subrugosa del Estrecho de Magallanes. Invest. Pesq. Santiago, 33: 25-32.

Saggiomo, V., A. Goffart, G.C. Carrada and J.H. Hecq. - 1994. Spatial patterns of photosynthetic pigments and primary production in a periantarctic ecosystem: the Strait of Magellan. $J$. Mar. Syst., 5: 119-142.

Saggiomo, V. and O. Mangoni. - 1997. Daily variations of primary production and photosynthetic parameters in Paso Ancho (Strait of Magellan). In: F.M. Faranda and L. Guglielmo (eds), Straits of Magellan, Oceanographic Cruise 1995. Data Report. 179-218.

Santelices, B. - 1989. Algas Marinas de Chile. Distribución, Ecología, Utilización y Diversidad. Ed. Univ. Católica de Chile, Santiago.

Smetacek, V., R. Scharek and E.M. Nöthig. - 1990. Seasonal and regional variation in the pelagial and its relationship to the life history cycle of krill. In: K.R. Kerry and G. Hempel (eds), Antarctic Ecosystems. Ecological Change and Conservation, pp. 103-114. Springer-Verlag, Berlin.
SooHoo, J.B., A.C. Palmisano, M.P. Lizotte, S.T. Kottmeier, S.L. SooHoo and C.W. Sullivan. - 1987. Spectral light absorption and quantum yield of photosynthesis in sea ice microalgae and a bloom of Phaeocystis pouchetii from McMurdo Sound, Antartcica. Mar. Ecol. Prog. Ser., 39: 175-189.

Vannucci, S. and V. Bruni. - 1997. Preliminary data on picoplankton and nanoplankton in the Straits of Magellan. In: F.M. Faranda and L. Guglielmo (eds), Straits of Magellan, Oceanographic Cruise 1995. Data Report: 171-178.

Vásquez, J.A., J.C. Castilla and B. Santelices. - 1984. Distributional patterns and diets of four species of sea-urchins in giant kelp forest (Macrocystis pyrifera) of Puerto Toro, Navarino Island, Chile. Mar. Ecol. Prog. Ser., 19: 55-63.

Vinuesa, J.H. - 1991. Biología y pesquería de la centolla (Lithodes santolla). Atlantica, Rio Grande, 13(1): 233-244.

Wefer, G., G. Fischer, D. Fütterer and R. Gersonde. - 1988. Seasonal particle flux in the Bransfield Strait, Antarctica. Deep-Sea Res., 35: 891-898. 